\title{
РУХОВА РЕАБІЛІТАЦІЯ ХВОРИХ ПІСЛЯ ОПЕРАЦІЇ З ПРИВОДУ ПІСЛЯТРАВМАТИЧНОЇ КОНТРАКТУРИ ЛІКТЬОВОГО СУГЛОБА
}

\author{
І. М. Курінний, О. С. Страфун, О. В. Долгополов, А. С. Герасименко
}

Інститут травматології та ортопедії НАМН України, м. Київ

\section{THE MOTOR REHABIILITATION IN PATIENTS AFTER OPERATION FOR POSTTRAUMATIC CONTRACTURE OF ARTICULATIO CUBITI}

\author{
I. M. Kurinniy, O. S. Strafun, O. V. Dolgopolov, A. S. Gerasymenko \\ Institute of Traumatology and Orthopedics, Kyiv
}

\begin{abstract}
Рефрерат
Вступ. Перелом в ділянці ліктьового суглоба (ЛС) становить 5 - 6\% в структурі всіх ушкоджень скелета, проте, частота незадовільних результатів лікування та утворення контрактури цієї зони сягає $20-25 \%$.

Матеріали і методи. Порівнювали ефективність розробки рухів під час реабілітації хворих, оперованих з приводу післятравматичної контрактури ЛС. Ретроспективний аналіз проведений у 69 пацієнтів з згинально-розгинальною контрактурою ЛС, яким виконували операцію артролізу. У пацієнтів 1-ї групи застосовували активну реабілітаційну програму без використання фріксуючих пристроїв; 2-ї групи - під час розробки рухів застосовували дві гіпсові шини у положенні максимального згинання та розгинання мобілізованого ЛС.

Результати. Після оперативного втручання та рухової реабілітації кінцевий обсяг згинально-розгинальних рухів у пацієнтів 1-ї

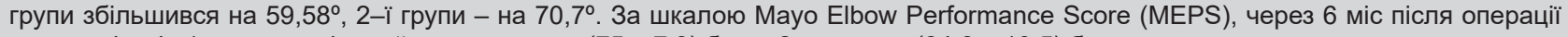
стан пацієнтів 1-ї групи оцінений у середньому $(75 \pm 7,3)$ бала, $2-і ̈$ групи - $(84,6 \pm 10,5)$ бала.

Висновок. Лікування післятравматичної контрактури ЛС є вкрай складною, актуальною проблемою, потребує індивідуального підходу.

При порівнянні ефективності реабілітації пацієнтів відзначене достовірне збільшення обсягу рухів та кращий фрункціональний результат за MEPS при використанні двох змінних гіпсових шин.

Ключові слова: ліктьовий суглоб; післятравматична контрактура; рухова реабілітація.

Abstract

Introduction. Fracture in region of articulation cubiti $(\mathrm{AC})$ constitutes $5-6 \%$ in structure of all injuries of skeleton, but the unsatisfactory results rate of treatment and creation of this zone contracture searches $20-25 \%$.

Materials and methods. Efficacy of the elaboration procedures application while the patients' rehabilitation course, who were operated on for the AC posttraumatic contracture, was compared. Retrospective analysis was conducted in 69 patients, suffering the AC flexingextensing contracture, in whom arthrolysis operation was done. In patients of group I an active rehabilitation program without fixing apparatuses was applied; in group II - while elaboration of movements two gypsum tires in position of maximal flexing and extension of the mobilized AC were used.

Results. After operative intervention and the motor rehabilitation a terminal volume of flexing-extension movements in patients of the group I have enhanced by $59.58^{\circ}$, and the group II - by $70.7^{\circ}$. In accordance to the scale of Mayo Elbow Performance Score (MEPS), in 6 mo postoperatively the state of patients in the group I was estimated at average $(75 \pm 7.3)$ points, and in the group II $-(84.6 \pm 10.5)$ points.

Conclusion. Treatment of the AC posttraumatic contracture is extremely complex and actual problem, and it demands individual approach application.

Trustworthy enhancement of the movements volume and the best functional result in accordance to MEPS while usage of two changeable gypsum tires were proved.

Keywords: articulatio cubiti; posttraumatic contracture; the motor rehabilitation.
\end{abstract}

Перелом в ділянці ЛС становить 5 - 6\% в структурі ушкоджень скелета, проте, лікування таких хворих складне у зв'язку з біомеханічними особливостями суглоба та високою частотою формування тяжкої згинально-розгинальної контрактури [1]. Зокрема, пошкодження ЛС посідає перше місце за частотою післятравматичних ускладнень, зумовлює стійку інвалідність 29,9\% пацієнтів [2]. Активне впровадження протоколів і стандартів АО з використанням первинно змодельованих пластин 3 блокованими гвинтами дозволило значно покращити функціональні результати лікування таких постраждалих.

Проте, частота незадовільних результатів, пов'язаних з незрощенням переломів або утворенням тяжкої контрактури, сягає 20 - 25\% [3].

у багатьох сучасних публікаціях, присвячених лікуванню післятравматичної контрактури ЛС, значну увагу приділено необхідності засто- сування адекватних післяопераційних програм рухової реабілітації.

Мета дослідження: порівняння ефективності двох видів реабілітаційних програм після хірургічного лікування післятравматичної контрактури ЛС.

\section{МАТЕРІАЛИ I МЕТОДИ ДОСЛІДЖЕННЯ}

В клініці мікрохірургії та реконструктивно-відновлювальної хірургії верхньої кінцівки лікували 69 па- 
Таблиця 1. Схема реабілітації хворих після мобілізуючої операції на лС

\begin{tabular}{|c|c|c|c|}
\hline \multirow{2}{*}{ Заходи реабілітації } & \multicolumn{3}{|c|}{ Етапи реабілітації } \\
\hline & I (5-6 тиж) & II (1,5 - $3 \mathrm{mic})$ & III $(3-4)$ mic \\
\hline $\begin{array}{l}\text { Іммобілізація у положенні } \\
\text { розгинання }\end{array}$ & Протягом доби & На ніч & Без іммобілізації \\
\hline Згинання у ЛС & Одноразове & 2-3 рази на добу & Багаторазове \\
\hline Фізіотерапевтичні процедури & $\begin{array}{c}\text { Магнітотерапія, } \\
\text { електростимуляція }\end{array}$ & $\begin{array}{c}\text { Фонофорез гідрокортизону, } \\
\text { електрофорез лідази }\end{array}$ & Парафін, грязелікування \\
\hline Медикаментозне лікування & $\begin{array}{c}\text { НПзП, протинабрякові } \\
\text { засоби }\end{array}$ & $\begin{array}{c}\text { Протизапальні гелеві та } \\
\text { мазеві засоби, препарати } \\
\text { кальцію }\end{array}$ & $\begin{array}{l}\text { Препарати кальцію, } \\
\text { хондропротектори }\end{array}$ \\
\hline
\end{tabular}

Примітка. НПЗП-нестероїдні протизапальні препарати.

цієнтів з приводу згинально-розгинальної контрактури ЛС, що виникла внаслідок травми та подальшого оперативного втручання в цій ділянці. Порівнювали ефективність розробки рухів під час післяопераційної реабілітації з приводу післятравматичної контрактури ЛС в двох групах пацієнтів: з застосуванням активної реабілітаційної програми без використання фіксуючих пристроїв та з застосуванням двох гіпсових шин на верхню кінцівку у положенні максимального згинання та розгинання мобілізованого ЛС.

Критеріями включення пацієнтів у дослідження були:

- контрактура ЛС, що виникла безпосередньо після травми чи операції 3 остеосинтезу дистального епіметафізу плечової кістки та/або проксимальних відділів кісток передпліччя;

- операція артролізу (мобілізації ЛС), яку виконували для усунення сформованої згинально-розгиналь- ної контрактури в ЛС, за неефективності консервативного лікування.

У хворих, включених у дослідження, не було патології кісток ЛС, що могло $б$ механічно перешкоджати рухам у ньому. Оперативне втручання виконували у 37 хворих 3 використанням латерального і медіального доступів, у 20 - заднього доступу, у 12 - латерального доступу. У більшості (41) пацієнтів операція супроводжувалась видаленням фіксаторів. В дослідження не включали хворих з післятравматичною згинально-розгинальною контрактурою ЛС, що супроводжувалась медіальною чи латеральною нестабільністю суглоба, а також з кістковими дефектами виростків плечової кістки та вінцевого відростка ліктьової кістки. В обох групах у пацієнтів відзначали консолідовані внутрішньосуглобові переломи дистального епіметафізу плечової та проксимальних метафізів променевої і ліктьової кісток, в тому числі з наслідками вида-

Таблиця 2. Оцінка стану хворих за шкалою MEPS

\begin{tabular}{|c|c|c|c|}
\hline Показник & $\begin{array}{l}\text { Кількість балів } \\
\text { (разом) }\end{array}$ & Визначення & Кількість балів \\
\hline \multirow{4}{*}{ Біль } & \multirow{4}{*}{45} & Не турбує & 45 \\
\hline & & Легкий & 30 \\
\hline & & Помірний & 15 \\
\hline & & Сильний & 0 \\
\hline \multirow{3}{*}{ Рухи } & \multirow{3}{*}{20} & Понад $100^{\circ}$ & 20 \\
\hline & & $50-100^{\circ}$ & 15 \\
\hline & & Менше $50^{\circ}$ & 5 \\
\hline \multirow{3}{*}{ Стабільність } & \multirow{3}{*}{10} & Стабільний & 10 \\
\hline & & Помірна нестабільність & 5 \\
\hline & & Значна нестабільність & 0 \\
\hline \multirow{5}{*}{ Функції } & \multirow{5}{*}{$\begin{array}{c}25 \\
\text { (кожен пункт +5) }\end{array}$} & Розчісування & 5 \\
\hline & & Вживання їжі & 5 \\
\hline & & Особиста гігієна & 5 \\
\hline & & Вдягання сорочки & 5 \\
\hline & & Взування & 5 \\
\hline Загалом ... & 100 & & 100 \\
\hline
\end{tabular}

лення головки променевої кістки.

За програмою післяопераційної реабілітації пацієнти розподілені на дві групи. У 29 хворих (1-ша група) застосована активна система рухової реабілітації. В основу системи покладений принцип: активні рухи з 2 - 3-ї доби після операції не менше 1 - 3 циклів щодня залежно від самопочуття. У 40 хворих (2-га група) застосовували систему дозованої динамічної реабілітації (табл. 1). Протягом 5 - 7 діб після операції пацієнти виконували один цикл згинання - розгинання з поверненням на ніч оперованої кінцівки в шину з повним або максимально можливим розгинанням у ЛС. На тлі зменшення після операції набряку та вираженості больового синдрому збільшували кількість циклів згинання-розгинання. Крім того, починаючи з 5 - 7-ї доби, гіпсували ЛС у положенні згинання під кутом $90-95^{\circ}$. Пацієнти носили згинальну шину протягом дня, знімаючи іiі під час виконання запланованих циклів згинально-розгинальних рухів, кількість яких поступово збільшували. На ніч хворим накладали гіпсову шину в положенні повного розгинання ЛС.

Обсяг згинально-розгинальних рухів в ЛС до оперативного втручання у хворих 1-ї групи становив у середньому $(44,69 \pm 12,25)^{\circ}, 2-\ddot{1}$ групи - $(48,05 \pm 12,15)^{\circ}$. Після мобілізуючої операції обсяг пасивних згинально-розгинальних рухів під наркозом у пацієнтів 1-ї групи - $(124,28 \pm$ $15,28)^{\circ}, 2-\ddot{1}$ групи - $(130,25 \pm 11,6)^{\circ}$.

Пацієнтів спостерігали в динаміці від першї доби після операції до 6 міс після неї. Під час контрольного огляду оцінювали амплітуду та безболісність рухів в ЛС. Фінальну оцінку здійснювали за шкалою MEPS (табл. 2). Отримані середні показ- 
ники порівнювали за допомогою тесту Ст'юдента для двох незалежних виборок.

Після підрахунку балів оцінювали результат: відмінний - понад 90 балів, хороший - 75 - 89 балів, задовільний - 60 - 74 бали, незадовільний - менше 60 балів. До оперативного втручання стан хворих 1-ї групи оцінений $(32,24 \pm 6,63)$ бала, $2-\ddot{1}$ групи - $(35,38 \pm 5,48)$ бала.

\section{РЕЗУЛЬТАТИ}

Динаміка рухової активності у пацієнтів 1 -ї групи через 2 - 3 тиж після операції мала активну тенденцію до зменшення обсягу рухів, незалежно від їх морально-вольових зусиль. Найбільш виражене зменшення обсягу рухів спостерігали у строки 6 - 8 тиж після операції, після чого відзначали поступову тенденцію до збільшення обсягу рухів. У хворих 1-ї групи досягнутий на операції обсяг пасивних згинально-розгинальних рухів у ЛС становив (124,28 \pm $15,28)^{\circ}$, поступово він зменшувався до $90^{\circ}$ за 1 міс після операції і до $70^{\circ}$ - протягом 2 міс. Лише на 3-му місяці відзначали поступове збільшення обсягу згинально-розгинальних рухів у ЛС до $70-85^{\circ}$, кінцевий обсяг через 6 міс становив у середньому $(104,28 \pm 9,42)^{0}$.

У 2-й групі активне відновлення рухів також починалось 3 першої доби після операції, використовували дві змінні шини - одну з кутом згинання $95-110^{\circ}$, другу - в повному розгинанні. При оцінці динаміки рухів через 3 - 6 тиж також спостерігали тенденцію до зменшення обсягу рухів, проте, вона була менш значною, ніж в 1-й групі, і мала більш активну динаміку в подальшому. Так, початковий обсяг рухів становив у середньому $(130,25 \pm 11,6)^{\circ}$, через 4 тиж після операції - $110^{\circ}$, через 8 тиж - $(100 \pm 19)^{\circ}$ з подальшою позитивною динамікою. На нашу думку, використання двох шин дозволило уникнути або зменшити динаміку поступового звуження досягнутого сектора рухів. Тому кінцевий обсяг рухів через 6 міс після операції у хворих 2-ї групи становив у середньому $(118,75 \pm 14,11)^{\circ}$.

Важливе значення у пацієнтів обох груп мали адекватне знеболення i протинабрякова терапія. Незважаючи на те, що під час мобілізуючої операції на ЛС ми намагались досягти повного обсягу пасивних рухів (у 86\% хворих обох груп нам це вдалося), або хоча б понад $100^{\circ}$ (у 14\% хворих), в обох групах відзначали тенденцію до зменшення обсягу активних і пасивних рухів і, відповідно, здобутків оперативного втручання під час реабілітаційного періоду. У пацієнтів за білыш тяжкого початкового ушкодження ЛС регрес обсягу активних і пасивних рухів у ЛС по дузі був більш вираженим.

У хворих 1-ї групи показник рухів до оперативного втручання становив у середньому $(44,7 \pm 12,30)^{\circ}$, $2-\ddot{i}$ групи - $(48,1 \pm 12,10)^{\circ}$; за шкалою MEPS до початку лікування в 1-й групі - (32,2 \pm 6,6) бала, у 2-й групі $(35,4 \pm 5,5)$ бала. Достовірних відмінностей середніх показників не було. Післяопераційна рухова реабілітація пацієнтів 2-ї групи забезпечила достовірно більші показники через 6 міс після оперативного втручання. Кінцевий обсяг згинально-розгинальних рухів у пацієнтів 1-ї групи становив у середньому (104,28 \pm $9,42)^{\circ}, 2-\ddot{1}$ групи - $(118,75 \pm 14,11)^{\circ}$. Таким чином, після оперативного лікування та застосування методики реабілітації обсяг рухів у хворих 1-ї групи збільшився на 59,58, $2-\ddot{1}$ групи - на 70,7 (у середньому обсяг згинально-розгинальних рухів в обох групах збільшився на $65,14^{\circ}$ ). За шкалою MEPS стан пацієнтів 1-ї групи через 6 міс після оперативного втручання оцінений у середньому $(75 \pm 7,3)$ бала, $2-і$ групи - $(84,6$

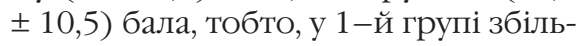
шився на $(42,8 \pm 8,9)$ бала, у 2 -й групі - на $(49,3 \pm 10,9)$ бала.

При порівнянні середніх показників обсягу рухів після операції, збільшення обсягу рухів та результатів оцінки за шкалою MEPS в обох групах відзначені статистично значущі відмінності цих показників.

\section{ОБГОВОРЕННЯ}

В зарубіжній літературі обговорюються два основні методи лікування хворих з приводу післяопераційної та післятравматичної контрактури ЛС, зокрема, динамічного та статичного прогресивного шинування $[1,3]$.

Пристрої $з$ шинування часто використовують для відновлення рухів у ЛС після травми або хірургічного втручання. Як правило, застосовують два типи шин. Статичні про- гресивні шини (за типом гвинтової стяжної/натяжної муфти), в яких застосований вплив статичних стресово-релаксаційних сил на тканини ЛС, що послідовно збільшуються, у міру збільшення обсягу рухів. Статичні прогресивні ортези тримають лікоть на кінці можливого діапазону рухів і передають коригувальні зусилля на суглоб в цьому положенні. Після того, як м'які тканини і капсула розтягуються у відповідь на таке позиціонування, діюча сила розсіюється. При цьому в шині змінюють прикладену силу для отримання більшого обсягу пасивних рухів. М'які тканини таким чином прогресивно подовжуються через цикли розтягування та звикання до отриманого кута.

у динамічних шинах застосовують постійну тривалу силу до тканин, що зберігається при досягненні додаткового обсягу рухів. Динамічні шини складаються з двох шин на передпліччя та плече, шарніру між ними і пружин, які можна встановлювати як на згинання, так і розгинання. Напруження тиску на ЛС підтримується на комфортному рівні за допомогою пружин. Динамічні ортези використовують пружину або еластичний елемент, який забезпечує постійне розтягування. У динамічному шинуванні тканини зазнають постійного навантаження, в той час як при статичному прогресивному шинуванні вони розтягуються з інтервалами [4]. При цьому тривале навантаження і розтягнення змінюють фіброзовані м'які тканини [5]. При статичному прогресивному шинуванні пацієнт керує величиною прикладеного навантаження шляхом його регулювання гвинтом-стяжкою до максимально можливого навантаження, яке він може перенести протягом тривалого часу.

У ретроспективному дослідженні [6] оцінені результати лікування контрактури ЛС 3 використанням динамічних шин у 17 пацієнтів з стабільними і конгруентними суглобами, з діапазоном рухів $100^{\circ}$ або менше, у яких обсяг рухів не збільшувався при використанні стандартних програм реабілітації. Збільшення обсягу рухів у ЛС через 4 міс динамічного шинування становило у середньому $(41 \pm 23)^{\circ}[6]$.

Поліпшення на $43^{\circ}$ обсягу згинально-розгинальних рухів відзна- 
чене у 12 пацієнтів з 15, у яких застосовані статичні шини [7]. Інші дослідники [8] повідомили про поліпшення у середньому на $31^{\circ}$ по дузі згинально-розгинальних рухів при використанні статичних шин. Хоча принципи мобілізації різні, при динамічному шинуванні відзначене поліпшення діапазону рухів, аналогічне такому при застосуванні статичного шинування [6, 7]. В нашому дослідженні також досягнуте значне збільшення обсягу рухів в ЛС, що по дузі становило у середньому $65,14^{\circ}$.

Після травми капсула суглоба потовщується і зазнає структурних змін (фіброзування), що частково відповідальні за обмеження рухливості в ЛС [5]. Динамічні ортези слід використовувати протягом тривалого часу для забезпечення біологічних реакцій, що супроводжуються пластичною деформацією тканин [8]. Якщо тканину розтягнути сильніше за межу іiі пружності, виникає травма. Якщо це відбувається неодноразово, тканини перестають розтягуватись [6]. Тому дуже важливо, щоб подовження м'яких тканин пацієнт переносив адекватно. Для досягнення цієї мети, насамперед, необхідно усунути всі м'якотканинні перешкоди для рухів, зокрема, розсікти фіброзно-змінену капсулу ЛС. Саме відновлення повного обсягу пасивних рухів у ЛС без напруження м'яких тканин під час оперативного втручання є базовою передумовою збереження обсягу рухів після операції. Сподівання на те, що обсяг рухів буде більший, ніж отриманий під час оперативного втручання (внаслідок реабілітаційних заходів, розробки рухів, тощо) у більшості спостережень є марними.

На відміну від інших дослідників, які не рекомендують використовувати динамічні шини вночі [9], ми вважаємо, що достатнього розтягнення можна досягти і в нічний час, оскільки тканини більш розслаблені. Пацієнти, які використовували шину правильно в нічний час, помічали поліпшення рухливості після того, як вони прокинулися. Тому однією з базових установок в реабілітаційному процесі 3 використанням

\section{REFERENCES}

1. Court-Brown CM, Caesar BC. Overview of epidemiology of fractures. In: Bucholz RW, Heckman JD, Court-Brown CM, et al., editors. Rockwood and Green's fractures in adults. Philadelphia: Lippincott Williams \& Wilkins; 2006:95-113. двох змінних шин $€$ утримування кінцівки в положенні розгинання в нічний час.

Тривалість шинування також обговорюється. $Є$ повідомлення, що сеанси тривалістю 30 хв дозволяють досягти хороших результатів та добре переносяться пацієнтами [8]. Інші дослідники рекомендують більш тривалі сеанси, зокрема, статичні шини протягом 15 год на добу [10]; динамічні шини протягом 16 год на добу [6]. При цьому 15317 пацієнтів були задоволені лікуванням і толерантні до такої інтенсивності застосування шин.

Щоб припинити суперечки щодо доцільності застосування двох методик лікування контрактури ЛС, вчені провели проспективне рандомізоване дослідження за участю 66 пацієнтів з використанням статичних прогресивних шин та динамічних шин в консервативному та післяопераційному лікуванні післятравматичної контрактури ЛС [11]. Порівнювали ефективність цих методів для відновлення рухів та усунення контрактури після травми або хірургічного втручання в ділянці ліктя. Істотні відмінності щодо збільшення обсягу згинання та розгинання та оцінки за DASH-опитувальником через 3, 6 і 12 міс шинування не виявлені. Поліпшення дуги згинання при застосуванні динамічного методу у порівнянні з статичним проявлялося збільшенням обсягу рухів у середньому на 30 та $28^{\circ}$ - через 3 міс, на 40 та $39^{\circ}$ - через 6 міс, на 47 і $49^{\circ}-$ через 12 міс від початку шинування. Автори дійшли висновку, що післятравматичну контрактуру ЛС можна усунути за допомогою ЛФК з динамічним чи статичним шинуванням протягом 6 - 12 міс, і таке тривале очікування результату є виправданим. Істотні відмінності статичних і динамічних прогресивних протоколів шинування ЛС не виявлені, отже, вибір методики може бути за пацієнтом чи фізіотерапевтом.

Схожі результати відзначені при аналізі досліджень, що стосувались консервативного лікування контрактури ЛС у дорослих [12]. Автори проаналізували всі повідомлен- ня щодо консервативного лікування контрактури ЛС англійською, німецькою, французькою та голландською мовами. Для аналізу даних відібрані 8 досліджень за участю 232 пацієнтів. Статичне прогресивне шинування застосоване у 160 пацієнтів. Діапазон рухів у ЛС до початку лікування становив $72^{\circ}$, після шинування збільшився на $36^{\circ}$, кінцевий обсяг рухів по дузі після лікування становив у середньому $108^{\circ}$. Динамічне шинування оцінене у 72 пацієнтів, діапазон рухів до початку лікування становив $63^{\circ}$, обсяг рухів збільшився на $37^{\circ}$, по дузі по завершенні лікування - становив $100^{\circ}$. Автори також не виявили переваг щодо застосування того чи іншого методу розробки рухів у ЛС.

Застосовані нами методики відрізняються від загальноприйнятих за рубежем, проте, принципово схожі на динамічну та статичну системи шинування. В нашому дослідженні методика післяопераційної розробки рухів у ЛС з застосуванням двох гіпсових шин має суттєві переваги порівняно з активною розробкою рухів без шинування.

\section{висновки}

1. Лікування післятравматичної контрактури ЛС є вкрай складною актуальною проблемою, потребуе індивідуального підходу.

2. При використанні системи активної розробки рухів у ЛС та системи розробки рухів з застосуванням двох змінних гіпсових шин спостерігали зменшення обсягу рухів після операції, максимальне - через 8 - 9 тиж. В подальшому спостерігали прогресивне збільшення обсягу рухів у ЛС.

3. При порівнянні ефективності реабілітації пацієнтів двох груп спостерігали статистично значуще збільшення обсягу рухів у 1 -й групі на $(59,6 \pm 14,8)^{\circ}$, у 2 -й групі - на (70,7 $\pm 17,1)^{\circ}$; кращий результат за MEPS: у $1-$ й групі - $(42,8 \pm 8,9)$ бала, у 2-й групі - $(49,3 \pm 10,9)$ бала, що свідчило про достовірно кращі результати в групі пацієнтів при використанні двох змінних гіпсових шин.
2. Asilova SU, Nurimov GK, Nazarova NZ, Rakhbarova DA. Sukhozhilno-myshechnye transpozitsii pri povrezhdeniyakh nervov verkhnikh konechnostey. In: Aktualnye problemy detskoy travmatologii, ortopedii i neyrokhirurgii. Tashkent; 2007:130-1. [In Russian]. 
3. O'Driscoll SW. Current Concepts in Fractures of the Distal Humerus. In: Morrey BF, editor. The Elbow and Its Disorders. Philadelphia: W.B. Saunders Co, 2009.

4. Ball CM, Meunier M, Galatz LM, Calfee R, Yamaguchi K. Arthroscopic treatment of post-traumatic elbow contracture. J Shoulder Elbow Surg. 2002;11:624-9.

5. Hildebrand KA, Zhang M, Hart DA. High rate of joint capsule matrix turnover in chronic human elbow contractures. Clin Orthop Relat Res. 2005;439:228-34

6. Gallucci GL, Boretto JG, Dávalos MA, Alfie VA, Donndorff A, De Carli $P$. The use of dynamic orthoses in the treatment of the stiff elbow. Eur J Orthop Surg Traumatol. 2014;24(8):1395-400.

7. Green DP, McCoy H. Turnbuckle orthotic correction of elbowflexion contractures after acute injuries. J Bone Joint Surg Am. 1979;61A:1092-5.

8. Bonutti M, Windau JE, Ables BA, Miller BG. Static progressive stretch to reestablish elbow range of motion. Clin Orthop Relat Res. 1994;303:128-34.
9. Doornberg MS, Ring D, Jupiter JB. Static progressive splinting for posttraumatic elbow stiffness. J Orthop Trauma. 2006;20:400-4.

10. Gelinas JJ, Faber KJ, Patterson SD, King GJ. The effectiveness of turnbuckle splinting for elbow contractures. J Bone Joint Surg $\mathrm{Br}$. 2000;82B:74-8.

11. Lindenhovius AL, Doornberg JN, Brouwer KM, Jupiter JB, Mudgal CS, Ring D. A prospective randomized controlled trial of dynamic versus static progressive elbow splinting for posttraumatic elbow stiffness. J Bone Joint Surg Am. 2012;94(8):694-700.

12. Veltman ES, Doornberg JN, Eygendaal D, van den Bekerom MP. Static progressive versus dynamic splinting for posttraumatic elbow stiffness: a systematic review of 232 patients. Arch Orthop Trauma Surg. 2015;135(5):613-7. 